\title{
Construction of Service Experience Management Framework under the Background of the Internet
}

\author{
Qian $\mathrm{Hao}^{1, \mathrm{a}}$, Guihuan Ren ${ }^{2, \mathrm{~b}}$ \\ ${ }^{1}$ Xi'an Vocational and Technical College, Xi'an 710077,China; \\ ${ }^{2}$ Shaanxi Vocational and Technical College, Xi'an 710100,China. \\ ahaoqian0710@163.com, bhuanwin@126.com
}

Keywords: Internet technology, Service experience, Management framework

\begin{abstract}
With the development of science and technology , the Internet commerce develop rapidly, consumers pay more attention to the personality and the emotional demands in the process of consumption , enterprise service management objectives will be upgraded to a 'satisfactory service' and 'unforgettable experience' . In this paper, I first define the concept of experience and service experience; secondly, I illustrate the significance of improving the service experience . Finally, I try to build a framework of service experience management under the background of Internet.
\end{abstract}

\section{Definition of the concept of experience and service experience.}

Alvin Toffler (1970) thinks that experience is a product of the psychological experience of goods and services, it has the 'economic value', and pointed out the experience based on simulation environment can make customers experience adventure, excitement or other fun[2]. In 1998, pine II and Gilmore in the Harvard Business Review article claimed that 'experience economy era has come[3]'. In 1999, the two's book figured that experience is 'a sense of good feeling when people's emotion ,physics, mental and even spirit reach a certain level ', and enterprise must engaged in the work of the creation of this' good feeling ','event 'and' reaction ' to achieve the target [4].

Service experience refers to a whole process of experience, and evaluation of this personal experience and subjective feeling by the consumer, the goal is to let consumers give a satisfactory evaluation and have a unforgettable feeling in the whole service process. Service experience has nouns and verbs, verb service experience is the whole process of customer service; while noun service experience is the customer evaluation of service process and psychological feelings.

\section{2 .Enhance the quality of service experience in the Internet era.}

With the rapid development of science and technology, the Internet has become a part of consumer's life, and is closely related to the lives of consumers, consumers can look for product information, purchase products, share purchases and uses of the product through the Internet. In the Internet era, enterprises must enhance the quality of service experience management.

2.1 Focusing on service experience helps to improve the quality of products and services. At the age of the Internet, the competition among enterprises is rather fierce, focusing on the service experience can find changes in demand and services, find the problems in time, and constantly improve the quality of products or services.

Good service experience can allow enterprises to avoid the impact of the commercialization of the enterprise. Deal with the fierce competition in the market, sensitive to changes in customer demand, help enterprises to better maintain the balance of supply and demand, between enterprises and maintain the customer emotion, let the enterprise business model is not easy to be imitated, so as to ensure the number of customers, to customers of the enterprise's reputation and loyalty.

2.2 The quality of service experience helps to cultivate the competitive advantage of enterprises. In today's global economydriven by Internet, enterprises are looking for differences between their rivals, service experience is unique and difficult to imitate, and this is the key to highlight the 
competitive advantage, good service experience will enable consumers to feel good, and they are willing to buy it again\&promote the experience so as to form a good image of the enterprise, to promote social acceptance of the enterprise, enhance corporate value, and cultivate the competitive advantage of enterprise.

2.3 Improving the quality of service experience helps to develop customer loyalty, retain customers. Internet is everywhere, consumers can search for the product's characteristics, function, price and after-sales service at any time; through social media, consumers can communicate with each other, thus form a strong public opinion. Improving the service quality of experience can make enterprises keenly aware of the changes of customers' demand, to help enterprises to better maintain the balance of supply and demandbetween enterprises, maintain the customer emotion, and make the enterprise business model not easy to be imitated. As a result, enterprisesensure the number of customers and contribute to customer loyalty.

\section{Construction of service experience management framework under Internet background.}

Good service experience promote the customer satisfaction, so that customers have a good, unforgettable service experience, and thus promote the customer loyalty, help to cultivate and maintain the competitive advantage of the enterprise. This paper attempts to build a framework of service experience management in Internet times, through the effective management of the service experience, to enhance the effectiveness of consumer service experience.Service experience management framework, as shown in Figure 1,including three levels : enterprise strategy, service management ,and Internet technology. The three levels have mutual contact, mutual support and can not be separated. Enterprise strategy is the superstructure of the service experience management , highlight directions and goals for the work of enterprise; Service management is the carrier of service management experience implementation, if the direction and goal has no specific implementation measures, everything is empty; Excellent Internet technology is the base of this frame and good service experience. Excellent Internet technology can achieve the goal of providing differentiated service satisfaction, and ultimately provide customers with 'unforgettable', 'satisfactory'service experience, both to meet customers needs, and to cultivate the competitive advantage of enterprises, maintain the profitability of the enterprise.

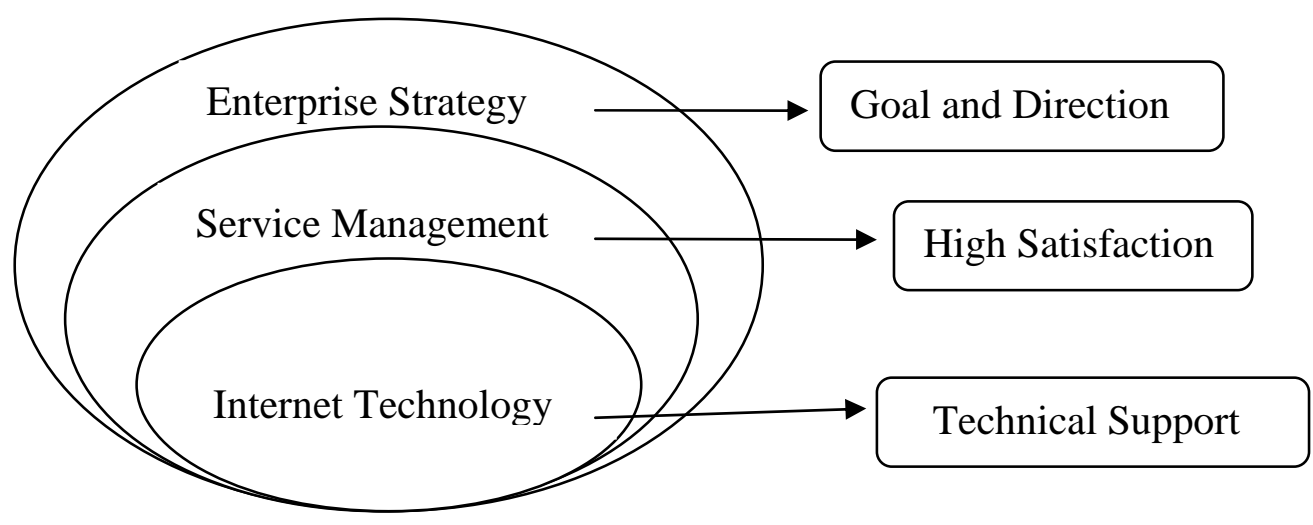

Fig. 1 Service Experience Management Framework

3.1 Enterprise strategy. Enterprise strategy set a goal for the service experience management, it will lose its direction without goals, even if the target has been reached, the enterprise does not have the coordination and measure of the standard without goals. The enterprise strategy has the overall effect in the whole framework , because the service experience has to meet customer demand, improve customer satisfaction, must have the correct direction and goals, to provide 'satisfactory service'and' good experience'to customers, carry out the service experience of each program, there must be 
attention and support by company leaders, or the service experience management in the enterprise is very difficult to realize.

Service experience management strategy focuses on establishing experience-centered management, to transform from'product-centered' to'customer-centered', enterprises should set the goal of providing customers with satisfactory memorable service, further meet the needs of target customers.

At the corporate strategic level, the enterprise mainly deals with the strategic vision and mission statement. Strategic vision and mission statement is the answer to 'what we think is what and become our mission', vision and mission statements should be lively and vivid, concise and comprehensive, easy to memorize and meaningful and inspiring. High level managers of enterprises should be clear and clear vision of the enterprise, clear and encouraging words to express, and pointed out that the future direction of the enterprise and the pursuit of the ideal. With the strategic vision of the enterprise, it should be transformed into the enterprise mission, enterprise mission should be inspiring and unique, let employees feel they are a valuable and unique group of a member of the mission should be specific and can avoid, let employees and the public feel that.

3.2 Service management . Service management is to study how to manage a enterprise successfully in competitive service environment.In today's society, regardless enterprises provide a tangible product or service products, or both, all enterprises are facing competition in service, if the enterprise only rely on tangible products, core services, will be difficult to establish lasting competitive advantage.

The enterprise should do everything through all kinds of activities to help customers create value, customer needs not only tangible products or services is the core, including delivery of integral service in the process of products and services, the enterprise comprehensive management is very necessary. Service competition is the competition between enterprises, enterprises only useful 'service logic' to manage the enterprise, not far from the expectations of customers, to meet customer demand, otherwise the enterprise will not survive in the competitive market.

Service management is the operating carrier, methods, practice, measures of the whole service experience framework, it provides consumers with memorable, satisfactory service, not on paper, verbally, but to carry out to every employee, every thing they do each day . First of all, the enterprise should do: intervening customer expectations, improving service capacity, beautifying the service environment, improving service quality, guiding customer behavior, encouraging customer feedback and improving recovery ability, innovating the service content continuously. Secondly, enterprises should focus on the point that customers are not satisfied to improve, so that customer satisfaction can be greatly improved, thus talking about service experience is meaningful. Finally, the enterprises should carry out the standardization services, and promote all the staff serve customers according to the specific characteristics on the basis of standard service, and establish a full service consciousness. 3.3 Internet technology . Internet technology refers to the information technology based on the computer technology, including hardware, software and applications. The Internet technology is the base of service experience management framework, the enterprise must enhance the consumer experience oriented service\&enterprise Internet technology to a strategic level.A good advanced Internet technology is the base of service management experience.

The use of Internet technology to a full range of customer information, the rapid development in information technology today, the customer information data is accurate, comprehensive and detailed is the basis of competition, is very important for the implementation of customer service management experience. Customer information should include: customer registration of personal information, trading records, service records, customer satisfaction, etc.. Enterprises can use this information to better understand customer needs, identify the most easy to impress customers and establish a good long-term relationship, high quality, and customer, which can produce good experience in customer service.

The use of Internet technology can realize big data management, a comprehensive grasp of consumers' personal information, the establishment of customer information database and to better understand the changing needs of consumers, and then targeted to meet consumers' demand; Internet 
technology can make the service more scientific, reasonable and systematic.as a result, it brings consumers good service experience, increases the interests of consumers; the Internet has profoundly changed the lives of consumers, consumers adhesion on the Internet, they always online at time pieces, at any time, rely on the circle, keen to share. WeChat, social contactAPP, timely communication applications and other social communication have become the mainstream application. The product or service of the enterprise will not be able to meet the needs of the consumers and be called the good Service experience if not combined with the Internet.

\section{Summary}

Under the background of Internet, The competition among enterprises is rather fierce, good service experience can bring consumers memorable service experience, improve customer satisfaction and loyalty, promote word-of-mouth marketing, thus retain consumers, increase consumers. This paper constructs three levels of service experience management framework, enterprise strategy, service management and Internet technology, these are all designed to enhance the quality of service experience, and cultivate the core competitiveness of enterprises.

\section{References}

[1] Philip Kotler, Kevin Lane Keller. Marketing Management 14th[M] . Pearson Education.( 2013)

[2] Alvin Toffler, Future Shock. [M]. Random House.( 1970)

[3]Pine II, B. J., Gilmore , J.H., welcome to the Experience Economy.[J]. Harvard Business Review, 1998, 76(7-8), 97-105

[4] Pine, J. and Gilmore, J. (1999) The Experience Economy, Harvard Business School Press, Boston, (1999)

[5]Roger W. Schmenner, How Can Service Business Survive and Prosper, Sloan ManagementReview, 1986.

[6]Christopher H. Lovelock, classifying Services to Gain Strategic Marketing Insights, Journal ofMarketing, 1983.

[7] Lonsway, Brian. (2009) "Making Leisure Work: Architecture and the Experience Economy," Oxford: Routledge Press.

[8] Gummesson E..Quality Management in Services Organizations [M].New York: International Service Quality Association, 1993

[9] Csikzentmihalyi, M. Flow: The Psychology of Optimal Experience. [M]. New York: Harper Perennial, 1991

[10] Csikzentmihalyi, M. Finding Flow: The Psychology of Engagement with Everyday Life. [M].

New York:BasicBooks,1997 